\title{
脳卒中患者に対する運動スキルの最適化を 図るための介入方略
}

\section{Intervention Strategy for Optimizing Motor Skill in Stroke Patients}

\section{潮見 泰藏1)}

TAIZO SHIOMI, PT, $\mathrm{PhD}^{1)}$

${ }^{1)}$ Department of Physical Therapy, School of Health Science, International University of Health and Welfare: 2600-1 Kitakanemaru, Otawara-city, Tochigi, Japan 324-8501. TEL +81 87-24-3123, FAX+81 287-24-3191

Rigakuryoho Kagaku 19(1): 1-5, 2004. Received Jan. 14, 2004.

ABSTRACT: The characteristics of movement disorders among stroke patients are mainly loss of voluntary control of the upper and lower limbs and trunk, or disability of functional movement. Functional recovery means the improvement of performance, functional movement ability, with respect to meaningful, practical problems in real life. This process can also be called the process of acquisition of skills in motor learning. In this paper, the current situation regarding physical therapy intervention, applying the theory of motor learning, as strategies for optimizing motor skills in stroke patients is explained.

Key words: stroke patient, motor learning, motor skill

要旨 : 脳卒中患者が有する運動障害の特徵は, 主として上下肢および体幹の随意的制御の消失ないしは低下によって 生じる機能的動作能力の低下である。機能回復とは, 現実的に意味のある具体的課題に対する遂行能力（機能的動作 能力）の向上を意味し, その過程は運動学習におけるスキルの獲得過程ということもできる。本稿では, 脳卒中患者 に対して運動スキルの最適化を図るための方略として, 運動学習理論を応用した理学療法的介入の実際について解説 した。

キーワード : 脳卒中, 運動学習, 運動スキル

1) 国際医療福祉大学保健学部理学療法学科 : 杤木県大田原市北金丸2600-1（テ324-8501）TEL 0287-24-3123 


\section{I. はじめに}

脳卒中患者に対する理学療法の主要な目標は, 機能的 動作の獲得である。機能的動作（すなわち, 具体的な運 動課題）を獲得することは，一つの運動スキルを最大化 する過程と言うこともできる。この運動スキルの獲得過 程には, 学習の原理が応用される。一方, 脳科学の進歩 によって, 脳はこれまで考えられていた以上に可塑性を 有することが明らかになってきた。特に, 脳傷害後の可 塑的変化と機能回復の関係については, この10年余りの 間に多数の研究成果が報告されている。

本稿では，これらの脳研究の成果と関連した脳卒中患 者の機能的動作における運動スキルの獲得過程に不可欠 な学習理論の具体的応用法について, 最近の知見をまじ えて解説する。

\section{II. 早期代償動作獲得の功罪}

脳卒中直後の運動皮質の興奮性は低下しており, 皮質 の投射領野は減少している。これは恐らく, ダイアスキー シス (diaschisis) の結果として起こるものと考えられる1)。 脳卒中後の初期に起こる機能回復とは梗塞巣周辺領域の 修復過程のことを意味している。これは浮腫や壊死組織 の吸収, あるいは傷害を受けた領域一の側副血行路の開 通など，局所の原因が解決されることによるもので，通 常3〜4週間程度の比較的短期間に起こると考えられてい る。しかし, 脳卒中直後の修復段階を過ぎた機能回復の カギを握る主要な過程とは, 「使用依存的再構築（usedependent reorganization)」である2)。

使用依存的再構築とは, 文字通り, 使用頻度に応じて, 大脳皮質の当該投射領野が変化するものであり, 使用が 著しく低下あるいはまったく使用しない状態が続くと, 投射領野は縮小寸る。Taubは，上記の非麻瘏側の上肢に よる積極的な代償によって麻瘏側上肢が使用されなく なった状態，すなわち，麻瘇側上肢が当初「使えない」 ために, 非麻痺側上肢による代償によって, ますます「使 わない」という図式 (悪循環) が形成され，この状況を 「学習された不使用 (learned unuse)」と表現している3)。

このことは片麻疩患者に対する下肢装具の適用につい ても当てはまる。すなわち, 足の背屈が不十分なために つま先離れが不良な場合, 装具（例：簡易型AFO）を用 いて足部の背屈を代償することにより歩行は容易にな る。しかし, 足部を努力して背屈することが不要となり, その結果, 足の随意的な背屈機能が改善されないまま経 過する可能性が高くなる。これも背屈能力を高め得る潜
在的な可能性を持ちながらも，機能性を優先した結果で ある。

こうした事実は,「非麻痺肢による代償動作を通じて早 期に機能を獲得する」という考え方を全面的に否定する ものではないが, 従来, 行われてきた麻痺肢へのアプロー チを再考寸る必要のあることを示唆しているものといえ よう。

一方，現在では，医療費の大幅な削減に伴い，多くの 医療機関で在院日数の短縮化が進み, それに伴い, より 効率の高い理学療法が求められるようになった。すなわ ち, 患者が短期間に, より高いレベルの機能に到達でき るよう援助することが，これまで以上に望まれている。 その意味で，いわゆる機能障害に対する治療的アプロー チに時間を費やす場合，介入期間，費用対比効果等を勘 案して，その適応を決定すると同時に，その根拠を明確 にすべきであろう。

\section{III. 脳傷害後の運動再学習の意義}

脳傷害後に現実の意味のある生活課題を通じて, 運動 やトレーニングを反復することによって残存した脳組織 内に新しく, しかも多くの効果的な結合を生み出寸上で 重要な刺激となるという仮説を立てることは合理的であ る。

中枢神経疾患に対する理学療法では「課題指向的アプ ローチ」が主流となりつつある。

これは1932年にBernsteinが提唱したシステム理論に根 拠をもつ。システム理論とは,「人間の運動や行動は何ら かの課題を遂行している状態であり, その課題の達成の ためにいくつかのシステムが動員されたり, 組織化され たり，ある行動パターンが生じる」とするものである4)。 すなわち, システムを構成する要素の相互作用によって, 機能的な課題が与えられた環境の中で効率よく遂行でき るようになる。なお，Bernsteinによれば，「運動は目的を 伴い，その目的を規定しているものは運動課題である」 とされ, 運動課題は外的刺激に対する単純な直接的応答 であることはほとんどなく, 常に何らかの「未来のモデ ル」，つまり，「達成すべきこと」を含んでいる4)。運動課 題には，これから何を達成したいかという心的な意図が 想定されており, 同時に恒常的で, しかも一定不変な結 果が求められている4)。

運動学習や再学習を促すような方法を用いてトレーニ ングや練習を行うことは新たな機能的結合を形成するの に不可欠と考えられる。脳内の可塑的変化として, 長期 増強や新シナプス形成（シナプス自体のもつ学習能力） 
という形で, 運動学習の初期段階に現存神経回路のシナ プス伝達効率の増加が起こると推測されている5)。

\section{IV. 課題特異性と学習の転移}

あるパフォーマンス状況から別の状況へ学習を転移さ せることは，スキルの学習にとって不可欠である。たと えば，バランスを含む姿勢調節は，課題（目標物に手を 伸ばすこと，立ち上がること，室内を歩くこと）と背景 (身体の位置, 環境の特性) に特異的である。課題や条件 における僅かな変化であっても, 筋活動のパターンに著 しい変化を生ずる。この特異性は, ある課題によるバラ ンストレーニングから別のバランストレーニングへ転移 する可能性に欠けている。例えば，立位学習の転移にお ける側方への体重移動を改善させるトレーニングによっ て，必ずしも歩行の安定性が改善されるわけではない。

側臥位で行われる麻痺側下肢の振り出しを促す運動 が，歩行時の下肢の振り出しに改善をもたらすかどうか については明らかではない。前者は, 安定した側臥位で, しかも非重力位で下肢の運動が行われるために患者は容 易であるが，後者では，立位保持そのものにバランスが 要求され，その上に一側下肢へ体重を移動し，対側の下 肢を振り出すため, はるかに難易度は高くなる。両者の 条件の違いはきわめて大きい。したがって, 学習の転移 の容易さを考慮するならば, 歩行中の下肢の振り出しを 改善するには，歩行時にパフォーマンスの修正を図るべ きである。

脳血管障害の多くは機能障害をもたらし, 筋が張力を 発生する能力や運動の制御, さらにある範囲の異なった 動作のパフォーマンスに影響を及ぼす。これまでの研究 から, ある程度満足のいくレベルのスキルは, 下肢に対 する機能的かつ特異的な筋力強化トレーニングと, 通常 の環境における動作のトレーニングによってのみ再獲得 されることがわかっている。

ここで, 中枢神経疾患患者における行動の再獲得では, 「代償 (substitution)」と「再学習 (relearning)」とは厳密 に区別されなくてはならない。運動障害を有する場合で も, 目的の達成のみを問題とするのであれば, それは学 習しなくとも数回の試行で代償的に獲得できる場合が多 い。但し，それは正常から大幅に逸脱した様式であるこ とが少なくない。したがって，この場合には単に合目的 的であることは必ずしも合理性を保証しない。

つぎに, 運動学習が生起するためには, 対象者の運動 能力に応じた学習目標を設定しなくてはならない。つま り, 対象者に介助がなくてはできない動作を目標とする
ことは意味がない。成功感や達成感を味わうことなく, 徒労に終わるトレーニングは，むしろ，注意や抑制など と同様, 「負の強化子」となる可能性がある。このこと は，引いてはそれが繰り返されることによって，学習さ れた無力感 (learned helplessness) を惹起しかねない。し たがって, 目標設定と課題の与え方には注意が必要であ る。

\section{V. 運動スキルとパフォーマンスの最適化}

理学療法の目標は, 個人が機能的活動における最大限 の技能パフォーマンスを再獲得し, 筋力や耐久性あるい はフィットネスの水準を高めることである。運動課題を 遂行するスキルは, 筋力, 耐久性, あるいはフィットネ スと同様，練習の量と形式の関数として増加する。しか も, スキルの上達は課題特異的に起こる。スキルの最適 化を図るとは, 現有する機能を最大限に利用し, 課題に 適応し，実用性の高い技能を獲得することにより，パ フォーマンスを高めることに他ならない。

スキル (技能) とは, 「最大の正確さと最小のエネル ギー消費，あるいは最短の時間と最小のエネルギー消費 によって, 相当な最終結果を引き起こす能力7)」である。 したがって，運動スキルの向上を図ることは，運動課題 に習熟することと関係がある。

運動スキルはつぎのような4つの構成要素からなる7)。

\section{運動スキル(skill) = フォーム(form) $\times$ 正確さ (accuracy) $\times$ 速さ (speed) $\times$ 適応性(adaptability)}

これら4つの要素は，獲得すべき動作の「実用性」に関 する評価項目でもある。運動スキルの向上は運動中の（無 駄な）筋活動の減少をもたらし，フォームがよくなるこ とは, その運動課題の遂行中に必要なエネルギーの減少, 寸なわち効率性に対応する。適応性とは環境条件が変化 してもパフォーマンスがあまり影響されないことを意味 する。運動スキルのトレーニングでは, はじめに, よい フォームをつくり，つぎに正確さに注意を向ける。初期 には速さを強調せず，ある程度，習熟してから，徐々に 速さと適応性を指導することが望ましいとされる7)。

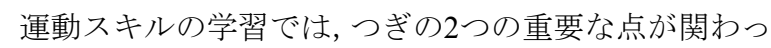
ている。

1. 学習すべきことが何かわかっていること

2. 目標を達成する方法を理解していること

注意の焦点をどこに当てるかということが，運動学習 や運動パフォーマンスに決定的な影響を与えることが証 


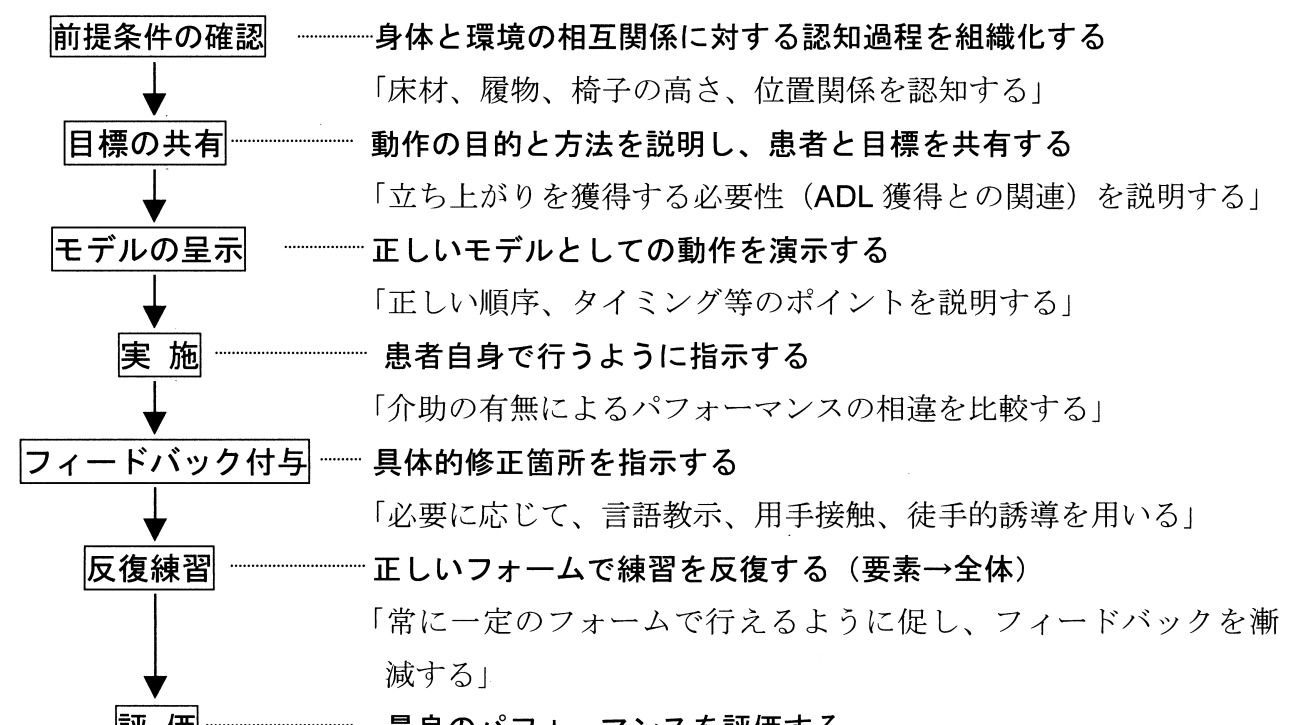

最良のパフォーマンスを評価する

「実用性を中心としたパフォーマンスの評価を行う」

図1「椅子からの立ち上がり」を例に運動学習を応用した練習的アプローチのモデル

明されている8)。練習中に患者が何に（どこに）注意を払 うべきか決定することが重要であり，注意の焦点を向け る方法には，演示 (demonstration) と指示 (instruction) が ある ${ }^{8)}$ 。前者は, 動作のモデル化によって, 患者に動作の 主要な構成要素を示す機会を与えることができる。そし て, 患者が空間的・時間的特性の概念を理解するのに役 立つ。後者は, 学習の初期段階では, 不必要な言葉は省 略し, 指示は端的に行うべきである。患者に1つないしは 2つの重要な特徵に集中する手がかりを与えることに役 立つ。

学習理論を応用した「椅子からの立ち上がり」では, 図1のような手順で, 練習的アプローチを進める。この場 合, 学習者 (患者) と教授者（セラピスト）の双方がこ のプロセスを理解し，トレーニングの目標を共有するこ とが必要となる。

立ち上がり動作は，座位では両足部と臀部から，立位 では両足部に支持基底面が移行する。同時に重心点は高 くなるため, 力学的には明らかに安定から不安定な状況 を迎える。しかも, 立位では股関節および膝関節の固定 に必要な筋活動が要求される。したがって, 正しいアラ イメントと安定性が保証されなくてはならない。

立ち上がりを練習する場合には，あらかじめ両足の幅 を広くとることによって, 立位への移行後の安定性に対 処する。さらに, 膝関節が $90^{\circ}$ 以上屈曲するように足部 を後方に配置する。伸展した頭部・体幹を十分屈曲し,
臀部の離床以降は速やかに頭部・体幹を伸展する。「(1)頭 部と体を前に傾け，(2)臀部が床から離れたら，速やかに 頭部・体を伸展させ立位になる。」この一連の動作をイ メージさせる。

つぎに，見本となる動作のモデルを呈示する。患者と 一緒に動作を行ってタイミング, 身体の位置を教示する。 巧くできた時にはタイミングよく集め, その時のフォー ムを繰り返しイメージさせることが大切である。また, 動作の手順を「言語化」しなくても，動作が確実に行え るようになるまで反復練習する。

一定の条件下で課題が達成されたら, さらに異なった 場面や環境下で, 同じ手順で試みる。すなわち,「立ち上 がった後, 歩いて別の椅子に座る」,「右手で水の入った コップを持ったまま立ち上がる」また，車椅子使用者で あれば，「車椅子から立ち上がり，ベッドへ移り，再び ベッドから車椅子へ戻る」というように複数の課題を取 り入れる。

課題指向的アプローチでは, 日常生活の様々な場面に 汎化されることが目標になるが，できるだけ実生活に近 い場面を設定しておくことが重要である。なお，椅子か ら正しく立ち上がるためには，この前提条件となる身体 （足）と環境（床）との相互関係に対する相互過程を組織 化する必要がある。

立ち上がり動作の初期の段階では，患者と基本的な運 動の協調性を獲得することに焦点を当てる。例えば，動 
作を反復することによって, 立ち上がり動作に必要不可 欠な時間的・空間的構成要素を高めるようにする。さら にスキルを最大化するための方略として，パフォーマン スの柔軟性のために, 練習によって様々な場面に対し, いかにパフォーマンスを適合させるかということを学ば なければならない。スキルのトレーニングでは，異なっ た制約条件下における立ち上がり動作の練習が含まれ る。

立ち上がり動作では, 椅子の高さ, 足の位置, 腕の使 用の有無, 運動速度, 運動方向等の多くの要因が関与す る。これらを「外部変数」と呼ぶことにするならば, 個 人の年齢や性別, 下肢筋力, 体幹・骨盤および下肢関節 の可動域, 感覚などは「内部変数」である。スキルを最 適化するには，個人の内部変数に応じて外部変数を制御 しなくてはならない。

中枢神経疾患患者の多くはこの一連の動作が困難とな ることが多い。その原因として, 足の関節の可動域制限 や, 体幹・骨盤の異常筋緊張や柔軟性の低下が挙げられ, これらは動作開始時の体幹前傾を妨げる。

立ち上がり動作を様々な状況で行えるようにするため に，次のような課題について練習を試みる。

1) 動作中の条件を変えてみる

(1)トレイの上にのせられた水の入ったグラスを持 ちながら行う

もしくは，片手でグラスを持ちながら行う

(2)大きさや重さの異なった物を持ちながら行う

(3)会話をしながら行う

(4)スピードを変えて行う

2) 動作の順序を変えてみる

立ち上がりした後，右または左方向へ歩き，もう一 つの椅子に座り, 立ち上がった後, 元の位置まで歩 いて戻り, 再び椅子に座る

3) バランスを失わずに動作を中止する

座面に対して大腿離地の直後または大腿接地の直前

4) 異なったタイプ（高さ, 形状）の椅子から行う

筋力トレーニングによって筋力増強を図る場合も, ス キルの上達を図る場合にも, 「反復すること」が練習の一 つの重要な側面である。患者が最適な方法を上達させる には, 何度も繰り返すことが必要となる。運動や動作の 練習を反復することによって, 健常者の場合も, 障害者 の場合にも, 関与する筋の収縮を促進し, パフォーマン スは向上する9-10)。
リハビリテーションの初期段階では，ある運動や動作 の一部を反復練習寸ることが筋力を増強し，分節的な結 合を動か寸筋の共同作用による協調性を鍛える必要であ る。そして, 反復練習中は, セラピストが患者に対する 動機づけを絶えず維持すべきである。

\section{VI. おわりに}

中枢神経疾患に対する理学療法では, その目的に応じ て, 治療的アプローチ, 練習的アプローチ, 調整的アプ ローチに大別される。課題指向的アプローチでは, 練習 的アプローチの要素が大きいが，これは単に一定の運動 を反復することを意味するのではない。現実的な環境条 件を前提として, 具体的な課題に対寸る処理能力を高め ることが站らいである。今後, 理学療法士に求められる 課題は, 運動学習の基礎理論とその適用方法を十分理解 し，実践できること，さらに脳科学の進歩に遅れずにつ いていくことである。

\section{文献}

1) Nudo RJ, Wise BM, Frost SB: Role of adaptive plasticity in recovery of function after damage to motor cortex. Muscle Nerve, 2001, 8: 1000-1019.

2) Nudo RJ, Friel KM: Cortical plasticity after stroke; implications for rehabilitation. Rev Neurol, 1999, 9: 713-717.

3) Taub E, Pidikiti RD, Delica SC, et al.: Effects of motor restriction of an unimpaired upper extremity and training on improving functional tasks and altering brain/behaviors. In: J.Toole (eds), Imaging and neurologic rehabilitation. New York, 1996, pp133-154.

4) Bernstein NA: The coordination and regulation of movement, Pergamon Press, London, 1967.

5) Asanuma H, Keller A: Neuronal mechanisms of motor learning in mammais. Neuroreport, 1991, 2: 217-224.

6) 中村隆一, 齋藤 宏: 基礎運動学 (第5版). 医歯薬出版, 東 京, 2000, pp 408-410.

7) Wulf G, McNevin N, Shea C: Learning phenomena: future challenges for the dynamical systems approach to understanding the learning of complex motorskills. Int J Psychol, 1999, 30: 120-126.

8) Carr J, Shepherd R: Storke rehabilitation. Butterworth Heinemann, 2002.

9) Butefisch C, Hummelsheim H, Mauritz K-H: Repititive training of isolated movements improves the outcome of motor rehabilitation of the centrally paretic hand. J Neurol Sci, 1995, 130, 56-68.

10) Dean CM, Shepherd RB: Task-related training improves performance of seated reaching tasks after stroke: a randomized controlled trial. Stroke, 1997, 28: 722-728. 